\title{
Maglev, Petroleum Demand, and Global Warming
}

\author{
Donald M. Rote ${ }^{\dagger}$
}

\begin{abstract}
According to the Intergovernmental Panel on Climate Change, combustion of petroleum-based and other fossil fuels results in the increasing atmospheric concentrations of $\mathrm{CO}_{2}$ and other greenhouse gases (GHG's) and is a major contributing factor to global warming. This paper includes estimates of the energy and petroleum use and the GHG emissions caused by the transportation sector. It then examines the extent to which diversions to alternative modes may be possible. Estimates are made of the potential reductions in energy and petroleum use and GHG emissions resulting from diversions from conventional modes, to both low-speed urban and high-speed intercity maglev vehicle trips based on "well-to-wheel" (i.e. total-fuel-cycle) calculations.
\end{abstract}

Key words : Maglev, GHG

\section{Introduction}

The continuing growth in demand for energy is not only contributing to the increase in energy prices but is arguably a leading cause of political conflict on both domestic and international scales. More and more countries are becoming net importers of primary fuels. According to Sample (2008), "More than half of the world's oil comes from seven countries". In addition, "twenty years ago, there were 15 oilfields able to supply 1 million barrels a day. Now there are only four". It is becoming increasingly apparent that we must find alternatives to fossil fuels. This is a particularly great challenge for the transportation sector, which is almost exclusively dependent of petroleumbased products. A recent editorial in the New Scientist (2008) has noted, "So we are presented with a choice: use the incentive created by high oil prices to push our transport systems towards low-carbon technologies, or remain at the mercy of speculators, saboteurs and the economic uncertainty that comes with high energy prices."

The problems associated with the energy crisis are not confined to purely economic issues. The combustion of fossil fuels is a major source of harmful emissions includ-

\footnotetext{
Corresponding author: Argonne National Laboratory, 9700 S. Cass Ave. Argonne, Il 60439-4803, USA, retired.

E-mail : drote@att.net
}

ing greenhouse gases (GHG's) whose atmospheric concentrations have

increased steadily since the beginning of the so-called industrial age (around 1750). Fig. 1 shows the exponential increase in $\mathrm{CO}_{2}$ concentrations measured at Mauna Loa and Antarctica during the last half century. According to

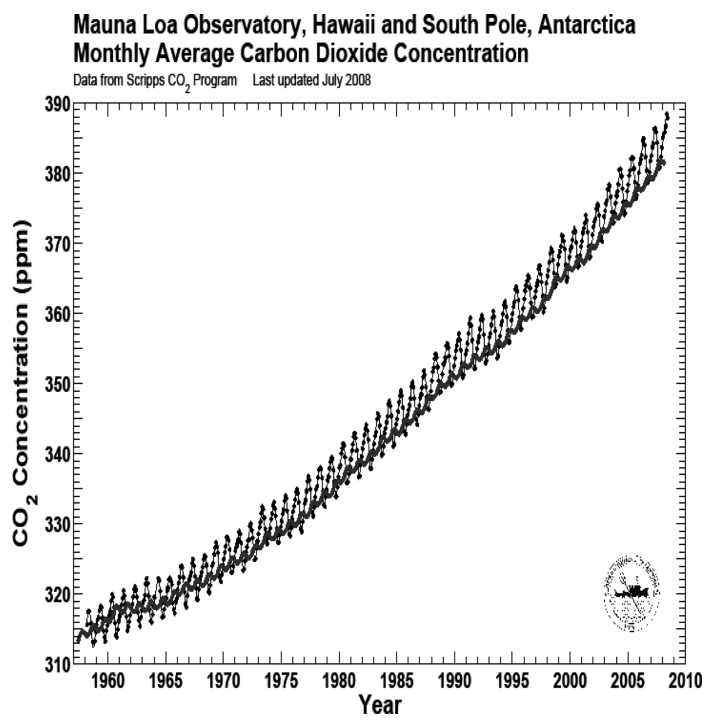

Fig. $1 \mathrm{CO}_{2}$ concentrations measured at Mauna Loa (upper black curve) and at Antarctica (lower red curve). Scripps (2008). 


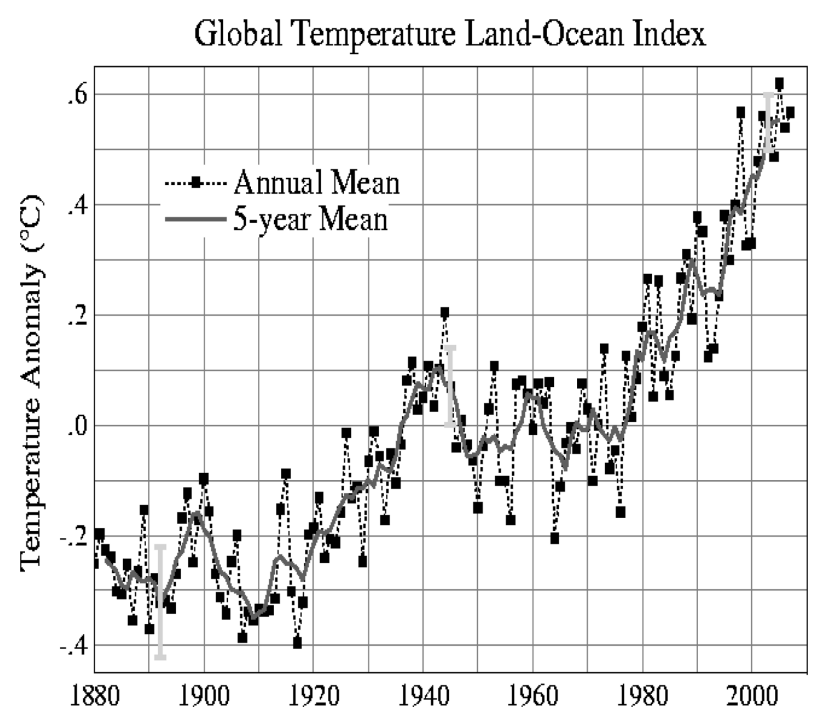

Fig. 2 The global temperature land-ocean index for the period 1880 to 2007 . The dotted black line is the annual averages and the smoother red line is the five-year running averages. The green bars are estimated errors. NASA GISS (2008).

the IPCC (2007a), the growth in GHG concentrations has been a major driver of global warming.

Fig. 2 shows the globally-averaged surface temperatures from 1880 to the present. Even if, as some skeptics have argued, the anthropogenic contribution to global warming is not important, the other impacts of the growing use of petroleum products would still warrant their significantly reduced use. And, such reduced use is tantamount to buying an insurance policy against the possibility of GHG impacts on global warming since displacement of petroleum based fuels by alternative, low-carbon or non-carbon based substitutes, would also reduce GHG emissions.

\section{Transportation Energy Use}

In the year 2004, transportation accounted for $26 \%$ of the total global energy use and $23 \%$ of the energy-related GHG emissions (IPCC, 2007b). During the period 19902002 the end-use sector with the highest growth rate was the transport sector. Of the $77 \mathrm{EJ}$ (exa joules, $1 \mathrm{EJ}=10^{\wedge} 18$ joules) consumed in that end-use sector, road vehicles account for $>75 \%$. Of that fraction, $95 \%$ comes from oilbased fuels; diesel, 23.6 EJ and gasoline, 36.4 EJ (31\% and $47 \%$ of the total transport energy, respectively). Table 1 shows the breakdown by transport mode.

Several organizations have recently projected future transport energy use. As reported in EIA (2005), the projected transportation energy use and total oil consumption depends heavily on the region. Mature market economies
Table 1. Global energy use by transport mode. IPCC (2007b)

\begin{tabular}{ccc}
\hline Mode & Energy (EJ) & Share (\%) \\
\hline Light-duty vehicles & 34.2 & 44.5 \\
\hline 2-wheelers & 1.2 & 1.6 \\
\hline Heavy freight trucks & 12.48 & 16.2 \\
\hline Medium freight trucks & 6.77 & 8.8 \\
\hline Buses & 4.76 & 6.2 \\
\hline Rail & 1.19 & 1.5 \\
\hline Air & 8.95 & 11.6 \\
\hline Ships & 7.32 & 9.5 \\
\hline Total & 76.87 & 100
\end{tabular}

are projected to increase their transportation energy use and oil consumption by $1.2 \% / y$ and $0.9 \% / y$, respectively, from year 2002 to 2025, whereas economies making the transition from state-run to market economies are projected to increase their energy use and oil consumption by $1.6 \% / y$ and $1.4 \% / y$, respectively, and emerging economies by $3.6 \% / y$ and $3.4 \% / y$, respectively.

In its most recent analysis, the EIA (2008), projected that the world transportation energy consumption would grow by $1.6 \% / y$ from 2005 to 2030 (comparable with the other end-use sectors).

However, whereas the other sectors, namely residential, commercial, and industrial, use mixtures of fossil fuels, electricity, and renewable energy sources, the transportation sector uses liquids (gasoline, diesel, ethanol, etc.) almost exclusively. Consequently, a significant reduction in petroleum use and associated GHG emissions can come from conservation measures and/or diversion of trips to clean low-carbon-based, or non-carbon based modes of transportation such as electrically-powered high-speed rail (HSR) and maglev.

\section{Transportation GHG Emissions}

Table 2 shows the equivalent $\mathrm{CO}_{2}$ emissions by economic sector in the U.S. As can be seen from Table 2, transportation is the second largest emitter of GHG's in the U.S. In terms of energy use, between 1973 and 2007, the transportation sector use increased from $24.6 \%$ to $28.5 \%$ of the total. Roughly $70 \%$ of the total consumption of petroleum in the U.S is by transportation. Roadway travel is responsible for more than half of the $\mathrm{CO}_{2}$ emissions in Germany and $42 \%$ worldwide. Table 2 also shows that electricity generation is the single largest emitter of GHG's. (Slightly over $50 \%$ of the electricity in the US is generated by coal combustion). Evidently, by diverting 
Table 2. U.S. GHG emissions ( $\mathrm{Tg} \mathrm{CO}_{2}$ equivalent) US EPA (2006)

\begin{tabular}{cccc}
\hline Sector & Year 1990 & Year 2004 & $\begin{array}{c}\text { \% of total for year } \\
2004\end{array}$ \\
\hline $\begin{array}{c}\text { Electricity } \\
\text { Generation }\end{array}$ & 1846 & 2338 & 33.0 \\
\hline Transportation & 1520 & 1955 & 27.6 \\
\hline Industry & 1439 & 1377 & 19.5 \\
\hline Agriculture & 486 & 491 & 6.9 \\
\hline Commercial & 434 & 460 & 6.5 \\
\hline Residential & 349 & 391 & 5.5 \\
\hline U.S. Territories & 34 & 62 & 0.9 \\
\hline Total Emissions & 6108 & 7074 & 99.9 \\
\hline Sinks (forests, etc.) & -910 & -780 & -11.0 \\
\hline Net Emissions & 5199 & 6294 & 89.0 \\
\hline
\end{tabular}

trips from carbon-based modes to modes using electricity generated by non-carbon-based fuels, substantial petroleum and GHG emissions could be saved.

\section{Air Travel}

As shown in Table 1, and as noted in the IPCC $4^{\text {th }}$ Assessment Report (2007b), light-duty vehicles, freight trucks, and air travel are the major energy use modes. Even though the air travel mode is only the third largest energy user, emissions from this mode are important for several reasons. First, as noted by the IPCC Report, civil aviation is one of the world's fastest growing transport modes. Second, aircraft fuel is not likely to be replaced by a low-carbon or non-carbon-based alternative in the foreseeable future. Third, aviation has a greater impact on radiative forcing than from just its $\mathrm{CO}_{2}$ emissions alone (see Sausen, et al. 2005). This is due to the emissions of $\mathrm{NO}_{\mathrm{X}}$, the formation of contrails, and the possible impacts on cirrus cloud enhancement. For the year 2000, radiative forcing of $\mathrm{CO}_{2}$ alone and in combination with the other impacts is estimated to be $25.3 \mathrm{~mW} / \mathrm{m}^{\wedge} 2$ and $48 \mathrm{~mW} / \mathrm{m}^{\wedge} 2$, respectively. Forster et al. (2007) estimates that for the year 2005, the combined radiative forcing would be $52.8 \mathrm{~mW} / \mathrm{m}^{\wedge} 2$. It is estimated that the aviation contribution to the total anthropogenic radiative forcing $\left(1600 \mathrm{~mW} / \mathrm{m}^{\wedge} 2\right.$ in year 2005) is about $3 \%$, with a range of 2 to $8 \%$. These estimates exclude the effect of cirrus cloud enhancement which has been estimated to be positive, but highly uncertain. If the latter effects were included, the radiative forcing from aircraft could be twice as large.

Consequently, in addition to possible improvements in aircraft performance, a feasible means of significantly reducing the civil aviation contribution is to substitute an alternative mode of transport such as HSR or maglev. Since maglev has greater speed and acceleration capabilities than HSR, it would be more likely to divert air travelers. Of course, to make the maximum improvement, the electric power needed for HSR or maglev should be generated by renewable energy sources, preferably closed-cycle nuclear energy (i.e. fast neutron reactors and pyrometallurgical fuel processing). As pointed out by former U.S. Senator Johnson from Louisiana (2008), "We cannot solve our $\mathrm{CO}_{2}$ problems without massive amounts of nuclear energy".

\section{Roadway Transportation}

With few exceptions, roadway vehicles used for passenger and freight transport utilize petroleum-based fuels. At present, a small fraction of gasoline and diesel fuel is displaced by biofuels. Future displacements are likely to result from increased use of biofuels and electric hybrid vehicles. In 2005, the total ethanol and biodiesel production in the U.S. amounted to about $2.9 \%$ and $0.21 \%$ of the total gasoline and diesel pools, respectively. According to the Energy Information Administration (2008), the AEO 2007 reference case projected that by 2030, ethanol blended gasoline will account for $7.6 \%$ of the total gasoline pool. However, it was noted there that "as ethanol production increases, competition for corn supplies among the fuel, food, and export markets, along with the marginal value of ethanol co-products, is expected to make production more expensive".

Obviously, if reducing both petroleum use and GHG emissions in the transportation sector is important, then attention should be focused on the major modes, namely light-duty vehicles, freight trucks, and aircraft.

\section{Diversion of trips from Air \& Road}

For the transportation sector, potentially significant reductions in petroleum use and GHG emissions could come from the diversion of trips from carbon-based to low or non-carbon based modes of travel. The question is: To what extent are diversions possible? Unfortunately, direct evidence of the extent to which people would shift their mode of travel to maglev is lacking. However, there is evidence that, given the right motivation, shifts to alternative modes of travel do occur. In the U.S., for example, the rapidly increasing price of gasoline is increasing the use of mass transit and increasing the sales of small and hybrid vehicles relative to large light-duty trucks (SUV's and vans). 
Table 3. Examples of recent increases in mass transit ridership due to gasoline price increases

\begin{tabular}{ccc}
\hline City & Transit Mode & \% Ridership Increase \\
\hline Denver & bus \& light rail & 9 \\
\hline Boston & subway & 9 \\
\hline Baltimore & light rail & 17 \\
\hline San Antonio & bus & 11 \\
\hline Seattle & commuter rail & 28 \\
\hline
\end{tabular}

On 6/20/08, the Lehrer News Hour (2008) reported that, due to gasoline price increases, ridership on several mass transit systems had increased significantly during the past year.

Undoubtedly, other mass transit systems not included in the Lehrer News Program exhibited similar ridership increases. With continued growth in fuel prices further increases in ridership are likely. In a study by Mattson (2008) it was reported that between 2002 and 2007, the gasoline price rose by $107 \%$. During that same period US ridership on light rail, commuter rail, and heavy rail increased by 35,13 , and $34 \%$, respectively. In his study, Mattson found that gas price elasticity ranged from 0.08 to 0.5 , and averaged 0.12 for small urban transit systems. This means that a $10 \%$ increase in gas price would result in a $1.2 \%$ increase in ridership. Whether these elasticities will remain the same as gas prices continue to increase is uncertain.

Whether, these changes are temporary or permanent remains to be seen. Regardless, these changes reflect the fuel price elasticity of mode choice. Obviously, the level of service and price of mass transit trips influence the degree to which people will leave their much-loved personal cars at home. A national opinion poll by a market research firm GFK (Cabanatuan, 2005) found that as the cost of fuel increases from $\$ 2.50$ to $\$ 5.00$ per gallon, the percentage of motorists indicating that they would switch to mass transit increases from $8 \%$ to $59 \%$, respectively.

CBS news (2008) noted that there has been a $25 \%$ increase in hybrid car sales in the last four months, and a $30 \%$ reduction in large SUV sales.

Clearly, these changes in transit ridership and vehicle preference brought about by gasoline price increases do not necessarily indicate what percentage of motorists would shift to new maglev systems if they became available. It would depend on what benefits or advantages such systems would offer.

Diversion of air trips to maglev is another potential source of petroleum and GHG reduction. Recent increases in airline ticket prices together with additional fees for
Table 4. Comparison of market shares by travel time in Japan. Shinkansen (Shin.) maximum operating speed is $300 \mathrm{~km} / \mathrm{h}$. JR (2004).

\begin{tabular}{cccccc}
\hline City Pair & Trip & Shin. & Airline & Total & Shin. \\
\hline & length & travel & flight & airline & market \\
\hline Tokyo to & $(\mathrm{km})$ & time & time & trip time & share \\
\hline Osaka & 515 & $2.5 \mathrm{~h}$ & $1 \mathrm{~h}$ & $2.5 \mathrm{~h}$ & $81 \%$ \\
\hline Okayama & 676 & $3.27 \mathrm{~h}$ & $1.17 \mathrm{~h}$ & $3.0 \mathrm{~h}$ & $60 \%$ \\
\hline Hiroshima & 821 & $3.85 \mathrm{~h}$ & $1.25 \mathrm{~h}$ & $3.17 \mathrm{~h}$ & $47 \%$ \\
\hline Fukuoka & 1069 & $4.97 \mathrm{~h}$ & $1.97 \mathrm{~h}$ & $2.67 \mathrm{~h}$ & $8 \%$ \\
\hline
\end{tabular}

checked luggage, fuel surcharges, and reduced service could prove to be strong motivations for switching to HSR and Maglev. Unfortunately, in the U.S., there are no HSR services other than along the Northeast corridor and, of course, no maglev systems in operation. However, some relevant data is available from countries where HSR systems are operational. For Japan, although trip diversion data is not available, at least it is possible to compare market share as a function of travel time. As shown in Table 4, for total travel times similar to airline trips, Shinkansen trains have over $50 \%$ of the market:

This comparison indicates that for similar total trip times (including access and egress times to city centers) people prefer the convenience, comfort, and reliability of HSR. Presumably, if the Shinkansen trains were replaced with the Japanese high-speed maglev system, which has greater acceleration and almost twice the maximum operating speed (up to $581 \mathrm{~km} / \mathrm{h}$ ), the maglev market share would exceed the airlines for all the city pairs shown in the table.

Turning to Europe, the fastest HSR systems are the TGV in France, the AVE in Spain, and the ICE in Germany. As noted by Vickerman (1997), the Paris/Lyon city pair is ideally situated for service by HSR. With a $2 \mathrm{~h}$ travel time over the $450 \mathrm{~km}$ distance, the TGV has been highly successful in diverting airline and highway traffic and generating new trips. In fact, because it is centrally located and the major focal point for many economic and cultural activities, Paris is an ideal city from which a HSR system could radiate outward. Train ridership along the Paris to Lyon corridor increased from 12.5 million in 1980 (one year before TGV began service) to 20 million by 1985 and 22.9 million by 1992 . The TGV accounted for 15 and 18.9 million passengers by 1985 and 1992, respectively. According to Vickerman (1997), "Paris-Lyon air traffic halved between 1980 and 1984, Paris-Geneve fell by around 20\% and Paris-Sud Est in general grew at less than half the rate of other radial routes from Paris". "Car traffic on the A6 parallel motorway grew at only about one-third 
the rate on the A4 and A13 routes". This data shows that the high-speed $(300 \mathrm{~km} / \mathrm{h})$ and other advantages of the TGV service can divert ridership from conventional rail as well as highway and air modes.

In Germany, during the first 5 years of operation, ICE ridership more than doubled from about 10 to 23 million passengers (Vickerman, 1997). Roughly $12 \%$ of this traffic was diverted from road and air, according to an estimate of Deutsche Bahn. The difference from the French TGV experience may be the result of Germany's having a more distributed array of urban centers as opposed to a single Paris-like focal point from which rail lines could radiate outward.

The Spanish AVE, after the first two years of operation, had 3.55 million passengers (Vickerman, 1997). About $32 \%, 25 \%$, and $14 \%$ were diverted from air, cars, and existing trains, respectively, with the remaining being newly generated.

It may reasonably be concluded from the Japanese and European experience with the introduction of HSR, that speed as well as other attributes, can divert significant numbers of passengers from existing modes. That bodes well for the US where intercity travel is dominated by air and road trips. Rail service outside of the Northeast corridor is almost entirely by diesel locomotive drawn trains that share rail lines with freight trains. Maximum speeds are limited to $79 \mathrm{mph}$. With growing congestion in urban areas and airports, and the limited speed of intercity trains, the attributes of both urban and intercity maglev systems appear very attractive and should be able to divert significant numbers of passengers from highway, rail and air modes. Given the small share of rail trips, diversions from air and road travel would be most effective in reducing petroleum use and GHG emissions.

\section{The Potential for Petroleum and GHG Emissions Reduction}

The energy and petroleum used and GHG's emitted by the production of fuels used by several transportation modes are listed in Table 5 on a per passenger-mile (PM) basis. These values are proportional to the fuel (in terms of Btu/PM) used by these modes. The total energy and petroleum used and GHG's emitted by these modes (the sum of the fuel production values and the fuel use values) are listed in Table 6. The values given in Tables 5 and 6 have been calculated based on information from the following sources:

- Energy intensity of autos, jet aircraft, intercity rail, urban rail, and buses ORNL (2007)

- Vans, SUV's, pickups US DOT (2007)
Table 5. Energy, petroleum, and GHG's to produce fuels

\begin{tabular}{|c|c|c|c|}
\hline & Energy to & Pet. to & GHG's to \\
\hline & produce & produce & produce \\
\hline & fuel & fuel & fuel \\
\hline & (Btu/PM) & (Btu/PM) & (g/PM) \\
\hline \multicolumn{4}{|l|}{ Intercity Modes } \\
\hline Auto & 502 & 226 & 44 \\
\hline Vans, SUV's, etc. & 678 & 305 & 59 \\
\hline Jet Aircraft & 549 & 266 & 52 \\
\hline Diesel-Electric rail & 114 & 54 & 11 \\
\hline HSR- U.S. Mix el. & 830 & 20 & 115 \\
\hline Maglev U.S. Mix el. & 1152 & 27 & 160 \\
\hline Maglev NG CC el. & 912 & 3.53 & 113 \\
\hline Maglev nuclear & 1361 & 0.05 & 4.06 \\
\hline \multicolumn{4}{|l|}{ Urban/Sub. Modes } \\
\hline Auto & 1030 & 464 & 90 \\
\hline Vans, SUV's, etc. & 1337 & 602 & 117 \\
\hline Bus - Transit & 762 & 360 & 72 \\
\hline Rail - urban - diesel & 498 & 235 & 47 \\
\hline Rail - urban - el. & 3883 & 92 & 538 \\
\hline Maglev U.S. Mix el. & 129 & 3.07 & 18 \\
\hline Maglev NG CC el. & 102 & 0.40 & 13 \\
\hline Maglev nuclear & 153 & 0.01 & 0.46 \\
\hline
\end{tabular}

- Energy, petroleum \& GHG emissions from nonnuclear fuel production GMC et al. (2001)

- Energy, petroleum \& GHG emissions from nuclear fuel production Wu et al. (2007)

- HSR, diesel/electric rail, maglev propulsion energy from the author's simulations and US ACE (1998)

High-speed intercity and low-speed urban-suburban modes are listed separately in Tables 5 and 6 . The values used for auto fuel economy (miles/gallon or mpg) (US EPA, 2007) and vehicle occupancy (persons per vehicle or P/V) (US DOT, 2004 and Des Moines, 2007) for intercity trips were $27.6 \mathrm{mpg}$ and $2 \mathrm{P} / \mathrm{V}$, respectively and for urban/ suburban trips $23.4 \mathrm{mpg}$ and $1.15 \mathrm{P} / \mathrm{V}$, respectively. For the electric-utility-based modes, three alternative primary energy sources are considered, electricity generated by the U.S. mix of fuels, the North American natural gas mix in combined cycle gas turbine power plants, and nuclear power plants. Intercity and urban maglev vehicles have maximum operating speeds of 483 and $100 \mathrm{~km} / \mathrm{h}$, respectively. Load Factors were assumed to be 0.80 .

It should be noted that the relatively large values shown for the urban mass transportation modes arise because of the small load factors used in ORNL (2007) for the US. 
Table 6. Total-Fuel-Cycle Energy, Petroleum, and GHG Emissions by Mode

\begin{tabular}{cccc}
\hline & Total & Total & Total \\
\hline & Energy & Petrol. & GHG \\
\hline & Used & Used & Emiss. \\
\hline & (Btu/PM) & (Btu/PM) & (g/PM) \\
\hline Intercity Modes & & & \\
\hline Autos & 2594 & 2318 & 192 \\
\hline Vans, SUV's, etc. & 3505 & 3132 & 260 \\
\hline Jet Aircraft & 3777 & 3494 & 285 \\
\hline Diesel-Electric rail & 749 & 689 & 57 \\
\hline HSR U.S. Mix el. & 1421 & 20 & 115 \\
\hline Maglev U.S. Mix el. & 1972 & 27 & 160 \\
\hline Maglev NA NG CC el. & 1732 & 3.5 & 113 \\
\hline Maglev nuclear & 2181 & 0.05 & 4.1 \\
\hline Urban/Suburban Modes & & & \\
\hline Autos & 5322 & 4294 & 395 \\
\hline Vans, SUV's, etc. & 6909 & 5575 & 513 \\
\hline Bus - Transit & 4997 & 4237 & 382 \\
\hline Rail - urban - diesel & 3262 & 2765 & 249 \\
\hline Rail - urban - el. & 6647 & 2764 & 538 \\
\hline Maglev U.S. Mix el. & 221 & 92 & 18 \\
\hline Maglev NA NG CC el. & 194 & 92 & 13 \\
\hline Maglev nuclear & 245 & 92 & 0.46 \\
\hline
\end{tabular}

Had load factors listed for developing countries in IPCC (2007b) been used, the urban mass transportation modes would have been lower by factors of 2 or 3 .

The GHG emissions from the electricity-powered modes all originate from the production of the primary energy sources. Evidently, modes powered by the electric utility grid use much less petroleum and emit much less GHG's than the other modes. The greatest savings would come from using electricity generated at nuclear power plants. Diversion from jet aircraft and intercity highway trips would save 281 and 188-256 g/PM of GHG's and 3494 and 2318-3132 Btu/PM of petroleum energy, respectively. Note that for conciseness, only the maglev option is shown with all three electric generating options. Clearly, all three options could apply to any electrically-powered mode.

\section{Conclusions}

As the world's population grows and countries develop economically, issues of resource supply and demand grow increasingly more difficult to manage. The growth in demand for fossil fuels, and in particular, petroleum-based fuels for the transportation sector, has led to serious domestic and international economic and political problems and threatens to become increasingly destabilizing. In addition, the combustion of fossil fuels leads to a host of potential health problems and to the increasing concentration of GHG's in the atmosphere that, in turn, impacts global warming.

This paper addresses the possible reduction in both the petroleum consumption and GHG emissions associated with the transportation sector. The diversion of trips from carbon-based to low or non-carbon based transportation modes has been shown to occur in Japan, Europe, and the U.S. Such diversions have resulted both from the rising costs of fuel, and the introduction of new modes of transportation including HSR. In the absence of data from commercially-operating maglev systems, it can only be assumed that the greatly reduced trip times and other benefits of maglev technologies will lead to trip diversions at least as large as those already discussed in this paper. It was shown that such diversions will result in significant reductions in petroleum consumption and GHG emissions on a per PM basis in corridors where such options become available.

\section{Acknowledgements}

I would like to acknowledge my wife Zenia Rote, whose encouragement and patience helped to make this paper a reality. I would also like to thank Andy Burnham and Anant Vyas, both from Argonne Natl. Lab., for providing me with pertinent documents and Zenia Rote, Caroline Herzenberg and Leo Herzenberg for carefully reviewing the manuscript and making helpful suggestions.

\section{References}

1. Cabanatuan, M. Oct. 2, 2005, www.sfgate.com/cgi-bin.

2. CBS News, 6/23/08, www.CBSNews.com

3. Des Moines Area Metropolitan Planning Organization, 2007 Vehicle Occupancy Survey, Feb. 2008.

4. EIA, Energy Information Administration, International Energy Outlook 2005, Table 3 Transportation Energy Consumption and Total Oil consumption by Region, 2002-2025.

5. EIA, Energy Information Administration, International Energy Outlook 2008, Report No. DOE/EIA-0484(2008), Table F1. Total World Delivered Energy Consumption by End-Use Sector and Fuel, 2005-2030.

6. EIA, Energy Information Administration, Biofuels in the U.S. Transportation Sector, 2008. eia.doe.gov/oiaf/analysispaper/biomass.html

7. Forster, P., V. Ramaswamy, P. Artaxo, et al.,Changes in Atmospheric Constituents and in Rdaiative Forcing, In:Cli- 
mate Change 2007: The Physical Science Basis. Contribution of Working Group 1 to the $4^{\text {th }}$ Assessment Report of the IPCC, Cambridge University Press, United Kingdom and New York, NY USA, 2007.

8. GMC, General Motors Corp., Argonne National Laboratory, BP, ExxonMobil, and Shell Report, Vol. 2, Well-to-Wheel Energy Use and Greenhouse Gas Emissions of Advanced Fuel/Vehicle Systems-North American Analysis- and Vol. 3, Well-to-Tank Energy Use and Greenhouse Gas Emissions of Transportation Fuels-North American Analysis- June 2001.

9. IPCC, Intergovernmental Panel On Climate Change 4th Assessment Report, Working Group 1 Report, Climate Change 2007: The Physical Science Basis, Ed. by S. Solomon, D. Qin, M. Manning, et al., Cambridge University Press, United Kingdom and New York, NY USA, 2007a.

10. IPCC, Intergovernmental Panel On Climate Change 4th Assessment Report, Working Group 3 Report, Mitigation of Climate Change, Chapter 5, Transport and its Infrastructure, Cambridge University Press, United Kingdom and New York, NY USA, 2007b.

11. Johnson, J. B., former U.S. Louisiana Senator, Presentation at the meeting of the American Nuclear Society, 2008.

12. JR, Central Japan Railway Co., Data Book, 2004.

13. Lehrer News Hour, 6/20/2008.

14. Mattson, M., Effects of Rising Gas Prices on Bus Ridership for Small Urban and Rural Transit Systems, Small Urban and Rural Transit Center, Upper Great Plains Transportation Institute, North Dakota State University, June 2008.

15. NASA GISS, Surface Temperature Analysis: August 2007 Update and Effects; Goddard Institute for SpaceStudies.giss.nasa.gov/gistemp/updates/200708.html.

16. New Scientist, Editorial, Withdrawal Symptoms, pg 5, 28 June, 2008.

17. ORNL, Oak Ridge National Laboratory, Center for Transportation Analysis, Transportation Energy Data Book, Chapter 2, 2007. http://www.cta.ornl.gov/data/chapter2.
18. Sample, I., Final Warning, New Scientist, pg 32-37, 28 June, 2008.

19. Sausen, R., I. Isaksen, V. Grewe, D. Hauglustaine, et al, Aviation Radiative Forcing in 2000: An Update on IPPC (1999), Meteorologische Zeitschrift, Vol. 14, No. 4, 555-561, August, 2005.

20. Scripps CO2 Program, 2008. scrippsco2.ucsd.edu/ graphics_gallery.

21. US ACE, US Army Corp of Engineers, Cold Regions Research \& Engineering Laboratory, Technical Assessment of Maglev Systems Concepts, Final Report by the Government Maglev System Assessment Team, J. H. Lever, Ed., Oct. 1998.

22. US DOT, US Dept. of Transportation, Federal Highway Administration, Summary of Travel Trends, 2001 National Household Travel Survey, Dec. 2004.

23. US DOT, US Dept. of Transportation, Bureau of Transportation Statistics, Table 4-20:Energy Intensity of Passenger Modes, 2007. http://www.bts.gov/egi-bin/breadcrumbs/

24. US EPA, Inventory of Greenhouse Gas Emissions and Sinks, chapter 2, April, 2006.

25. US EPA, Compliance and Innovative Strategies Div. and Transportation and Climate Div. Office of Transportation and Air Quality, Light-Duty AutomotiveTechnology and Fuel Economy Trends: 1975-2007.

26. Vickerman, R., High-Speed Rail in Europe: Experience and Issues for Future Development, The Annals of Regional Science, Springer-Verlag, Vol. 31 pg 21-38, 1997.

27. Wu, Y., M. Wang, A. Vyas, D. Wade and T. Taiwo, Well-toWheel Analysis of Energy Use and Greenhouse Gas Emissions of Hydrogen Produced With Nuclear Energy, Nuclear Technology, Vol. 155, pg 192-207, August, 2007.

Received(July 10, 2012), Accepted(August 6, 2012) 